\title{
The where, when and what of phosphorus fertilisation for seedling establishment in a biodiverse jarrah forest restoration after bauxite mining in Western Australia
}

Article

Accepted Version

Creative Commons: Attribution-Noncommercial-No Derivative Works 4.0

Tibbett, M., Daws, M. I., George, S. J. and Ryan, M. H. (2020) The where, when and what of phosphorus fertilisation for seedling establishment in a biodiverse jarrah forest restoration after bauxite mining in Western Australia. Ecological Engineering, 153. 105907. ISSN 0925-8574 doi: https://doi.org/10.1016/j.ecoleng.2020.105907 Available at https://centaur.reading.ac.uk/91009/

It is advisable to refer to the publisher's version if you intend to cite from the work. See Guidance on citing.

Published version at: $\mathrm{http}: / / \mathrm{dx}$.doi.org/10.1016/j.ecoleng.2020.105907

To link to this article DOI: http://dx.doi.org/10.1016/j.ecoleng.2020.105907

Publisher: Elsevier

All outputs in CentAUR are protected by Intellectual Property Rights law, including copyright law. Copyright and IPR is retained by the creators or other copyright holders. Terms and conditions for use of this material are defined in the End User Agreement. 


\section{www.reading.ac.uk/centaur}

\section{CentAUR}

Central Archive at the University of Reading

Reading's research outputs online 
1 The where, when and what of phosphorus fertilisation for seedling establishment in a

2 biodiverse jarrah forest restoration after bauxite mining in Western Australia 3

4 Mark Tibbett $^{1,2^{*}}$, Matthew I. Daws ${ }^{1}$, Suman J. George ${ }^{3}$, Megan H. Ryan ${ }^{3}$

5

$6 \quad{ }^{1}$ Department of Sustainable Land Management and Soil Research Centre, School of

7 Agriculture Policy and Development, University of Reading, Berkshire, RG6 6AR, United

$8 \quad$ Kingdom

$9 \quad{ }^{2}$ School of Biological Sciences, The University of Western Australia, Crawley, WA 6009,

10 Australia

$11{ }^{3}$ School of Agriculture and Environment, The University of Western Australia, Crawley, WA

126009 , Australia

$13 *$ Corresponding author

14

15 Key words: fertiliser, legume, nitrogen, rehabilitation,

16 


\section{Abstract}

18 Fertiliser application to restore nutrients lost in the mining process and facilitate early plant

19 establishment and growth is a key step in the restoration of sites disturbed by mining.

20 However, few studies have investigated the effects of different fertiliser types and application

21 methods on mine restoration outcomes, especially in highly biodiverse ecosystems such as the jarrah forest. This forest is a unique, floristically diverse landscape with species adapted to growth on highly weathered phosphorus impoverished Ferralsol. In this study we investigated the effect of fertiliser type (rock phosphate, single superphosphate, and an NPK fertiliser), application method (top-dressed versus incorporated), and the timing of application (winter vs. summer) on the trajectory of jarrah (Eucalyptus marginata) forest restoration

27 following bauxite mining compared to an unfertilised control. All fertilised soil had elevated Colwell-P concentrations (bar rock phosphate) and had considerably less $\mathrm{N}$ than found in the native forest, even after $\mathrm{N}$ fertilisation. Fertiliser incorporation resulted in a more even

30 distribution of $\mathrm{P}$ down the soil profile and increased overall plant growth (as assessed by

31 percentage cover) compared with either top-dressed fertiliser application and no fertiliser,

32 potentially offering better erosion control. In contrast, native species richness was highest in the zero fertiliser and NPK treatments and lowest in the phosphorus incorporation treatments. On average, unfertilised plots had 10 more native species per plot than those fertilised with $\mathrm{P}$ only. Fertiliser application also reduced the abundance and cover of Bossiaea ornata and Lomandra spp., both of which are small slow-growing understorey taxa. In contrast, the legume Acacia celastrifolia exhibited a vigorous growth response to fertiliser, with growth being greatest when $\mathrm{P}$ (either rock phosphate or SSP) was incorporated. These data suggest that $\mathrm{P}$ fertiliser incorporation is a potential strategy to both maximise early plant growth and

40 cover and increase the efficiency of $\mathrm{P}$ application. However, if the goal of restoration is to 
41 maximise diversity then moderation in $\mathrm{P}$ application and using fertilisers that also contain $\mathrm{N}$ 42 and K may be appropriate.

43

44 Keywords: Acacia, biodiversity, fertiliser, legume, nitrogen, rehabilitation 


\section{Introduction}

Vegetation removal and the processes of soil removal, stockpiling and mixing when soil is stripped and respread result in significant losses and redistribution of soil nutrients during the mining process. Consequently, applying fertiliser to replace lost nutrients is generally viewed as a key step in the restoration of sites disturbed by mining (Tibbett, 2010). Fertiliser addition is also regarded as beneficial by increasing plant growth and thereby reducing the risk of erosion in newly restored (bare) sites (Ward et al., 1990). However, the effects of different fertiliser types and application methods in post mining restoration have received relatively little attention.

Both neutral and positive effects of fertiliser application on plant growth have been observed in restored mine sites (e.g. Malakondaiah et al., 1981; Wali, 1999; Rokich and Dixon, 2007; Williamson et al., 2011; Soliveres et al., 2012), which suggests species-specific responses to fertiliser that may, in turn, affect competitive interactions among species. For example, fertiliser addition reduced seedling survival of some woody species in quarry restoration in Spain due to increased competition with herbaceous species (Soliveres et al., 2012) and increased mortality of proteoid shrubs in fynbos restoration in South Africa (Holmes, 2001). In addition, fertiliser application can increase the growth and establishment of weed and native annuals with negative impacts on native species richness and slower growing species (Daws et al., 2015, 2019a; Nussbaumer et al., 2016). Consequently, there is a need to better understand fertiliser impacts on both species responses and community composition in mine site restoration.

The jarrah (Eucalyptus marginata) forest in Western Australia has highly weathered, nutrient deficient soils. Post mining restoration in this, and other environments with nutrient deficit soils can result in soil phosphorus concentrations remaining elevated for 20 or more years after a single, initial fertiliser application (e.g. Banning et al., 2008; Spain et al., 2018; 
70 Daws et al., 2019b). In contrast, when fertiliser containing inorganic $\mathrm{N}$ is applied, $\mathrm{N}$ is often rapidly lost (Daws and Richardson, 2015; Sloan et al., 2016). For example, in newly restored jarrah forest, a single application of $40 \mathrm{~kg} \mathrm{~N} \mathrm{ha}^{-1}$ is undetectable after just 4.5 months (Daws and Richardson 2015). As a result, it is common practice for eucalypt forest restoration after bauxite mining to receive fertiliser only containing P (e.g. Standish et al., 2010; Spain et al., 2018), based on the assumption that $\mathrm{N}_{2}$-fixing legumes, which are likely to increase $\mathrm{N}_{2}$ fixation in response to P-application (Hingston et al., 1982), will increase soil-N (Grant et al., 2007). However, any potential impacts on the restored plant community of applying solely $\mathrm{P}$ based fertiliser, rather than fertiliser also containing $\mathrm{N}$, have not been assessed.

In post mining restoration, inorganic fertilisers are typically applied as a top-dressing (e.g. Koch, 2007; Nussbaumer et al., 2016; Sloan et al., 2016). For example, in jarrah forest restoration following mining for bauxite, newly restored sites are top-dressed with fertiliser the first winter/spring after the completion of restoration and seeding in the preceding summer (Koch, 2007; Standish et al., 2015). However, P in these fertilisers is likely to remain concentrated at the soil surface. For example, in agricultural systems vertical stratification of P can occur when fertiliser is either top-dressed or shallow buried adjacent to seeds (Eckert, 1985; Mackay et al., 1987; Morrison and Chichester, 1994; Ryan et al., 2017). Furthermore, the availability of shallow/surface applied fertilisers to plants is likely to be restricted in restored mine sites where rapid drying of surface soils may occur. This will particularly be the case for $\mathrm{P}$, as diffusion of phosphate ions to plants is limited in dry soil (Nye and Tinker, 90 1977). Indeed, surface application limits $P$ uptake in a range of agricultural systems (Piper and de Vries, 1964; Scott, 1973; Jarvis and Bolland, 1991), with incorporation of P fertiliser increasing crop yields relative to surface applications in a number of studies (Nable and

93 Webb, 1993; Sander and Eghbell, 1999; Teutsch et al. 2000; Singh et al. 2005).

94 Consequently, the benefits to plant growth of fertiliser application in restored mine sites may 
be greater when the fertiliser is incorporated into the soil rather than applied as a topdressing. However, this remains to be tested.

In jarrah forest restoration, fertiliser is typically applied the first winter after the completion of earthworks in the preceding summer (Koch, 2007): establishing seedlings may be several months old before fertiliser is applied. However, responses to fertiliser addition may be expected to be greater if the applied fertiliser is available to establishing seedlings from the onset of germination in autumn. While this remains to be tested, anecdotal evidence shows various trends for some key native jarrah forest species: spring fertiliser application produced optimal growth for some keystone jarrah forest species (Humphrys, 1987), while Lockley and Koch (1996) found summer application (at the time of seeding) produced a higher density of jarrah seedlings.

In this study, we investigated the effects of a range of fertiliser treatments on establishment of one-year-old jarrah forest in the process of being restored after bauxite mining in Western Australia. Specifically, we investigated whether fertiliser incorporation versus a top-dressed application impacts on the distribution of available (Colwell) $\mathrm{P}$ in the soil profile and tested the hypothesis that incorporation will result in greater plant growth. Secondly, we assessed the effect of fertiliser application relative to an unfertilised control to test the hypothesis that fertiliser application will increase overall plant growth, but increase weed abundance and reduce native plant species richness. Thirdly, we tested the effect of fertilisers containing only P (including slow release rock phosphate and highly soluble single superphosphate) compared with an NPK-based fertiliser on plant responses to test the hypothesis that applied-N will have limited impact on vegetation responses due to only shortterm availability after application. Finally, we tested the effect of the timing of fertiliser application (summer versus winter) on plant responses, to test the hypothesis that a greater 
119 response will be evident when fertiliser is present from the onset of germination / seedling

120 emergence (i.e. when applied in summer).

\section{2. METHODOLOGY}

\section{2.1. Description of study location}

124 The experiment was established in the northern jarrah forest of Western Australia located approximately $130 \mathrm{~km}$ south-east of the state capital Perth $\left(32^{\circ} 48^{\prime} \mathrm{S} 116^{\circ} 28^{\prime} \mathrm{E}\right)$. The region experiences a Mediterranean climate with hot, dry summers and mild, wet winters. Mean January and July temperatures are 32.1 and $15.8^{\circ} \mathrm{C}$, respectively and total rainfall is approx. $720 \mathrm{~mm} \mathrm{yr}^{-1}$ and strongly seasonal, most falling during the winter months of June to August (Australian Bureau of Meteorology, 2021).

131 marginata (jarrah), which constitutes around $80 \%$ of stems in both restored and unmined

132 forest (Daws et al., 2015). The remaining stems are mostly comprised of the subdominant

133 species Corymbia calophylla (marri). In addition, there is a mid-storey layer of Banksia grandis, Allocasuarina fraseriana and Xanthorrhoea preisii with large woody shrubs of Bossiaea aquifolium, various Acacia species and a diverse understorey (Gardner and Bell,

136 2007). Jarrah forest soils developed on ca. 2.6-billion-year-old granite-gneiss metamorphic

137 batholith of the Yilgarn craton (Nemchin \& Pidgeon, 1997), within the bauxitic province of

138 the Darling Range (McArthur, 1991). Here, the deep weathering of regolith is among the

139 oldest in the world, with weathering events as early as the Cretaceous Period. This has led to

140 subsoil accumulation of bauxite ores and also a depletion of nutrients, particularly

141 phosphorus. The resulting soils are gravelly with low concentrations of available N, P and K

142 (Table 1 and see Hingston et al., 1989) with high rates of phosphorus fixation on the 
remaining amorphous iron and aluminium oxides. Generically these soils are classified as

144 lateritic oxisols (USDA, 1999) or ferralsols (FAO, 2012).

\subsection{Experimental design}

147 A large-scale field experiment was established in April 2004 at two previously surfaced-mined 148 sites with the objective of studying the effects of ground-based phosphorus fertiliser

149 application (type of fertiliser, placement and time of application) on restoration. The area was

150 cleared of native jarrah forest vegetation in 2002, two years prior to the commencement of this

151 experiment. During the two years following vegetation clearing, topsoil and gravel overburden

152 were removed to expose the bauxite ore which was blasted and mined. Subsequently the area was re-shaped to blend in with the surrounding landscape and the entire area deep-ripped to relieve mining-related compaction. The overburden was then replaced followed by fresh topsoil sourced from an adjacent area that had just been cleared for mining. Due to the

156 processes of being stripped, transported to and then re-spread across the area being restored,

157 the topsoil spread across the trial sites was relatively homogenous.

Following topsoil replacement, but prior to a final contour ripping stage, an incomplete randomised block design was established at both sites. Six treatments that were operationally feasible, including the current prescription of applying fertiliser as a broadcast treatment in the

161 winter following seeding (Table 2), were established. The design was incomplete as

162 impractical treatments such as fertiliser incorporation in winter were excluded. For example,

163 this treatment would result in both the burial of emerging seedlings and soil compaction due to wet soil conditions. Treatments were replicated either 8 times (the 3 single super phosphate [SSP] treatments) or 4 times (the control, NPK or rock phosphate) (Table 2). Treatment plots

166 were $25 \times 25 \mathrm{~m}$ in size. In the incorporation treatments, fertiliser was applied prior to the final

167 contour ripping with the ripping step used to incorporate the fertiliser down the soil profile. 
168 Tines incorporated material to a depth of approximately $1 \mathrm{~m}$. Following contour ripping, a seed mix of 162 species representing forest sub-types of northern Jarrah forest (comprising understorey and tree species) was broadcast at the rate of $88 \mathrm{~g} \mathrm{plot}^{-1}$. Acacia celastrifolia was not included in the seed mix as it was well represented in the soil seed bank. In the broadcast

172 fertiliser treatments, fertiliser was applied by hand once contour ripping had taken place, either immediately (summer) or in the following winter. calcium, $0.6 \%$ copper, $0.3 \%$ zinc and $0.06 \%$ molybdenum; 2) NPK (commercial name K-Till) at $340 \mathrm{~kg} \mathrm{ha}^{-1}(8.6 \% \mathrm{~N}, 12.0 \% \mathrm{P}, 9.8 \% \mathrm{~K}, 6.7 \% \mathrm{~S}, 3.8 \% \mathrm{Ca}, 0.1 \% \mathrm{Cu}$ and $0.2 \% \mathrm{Zn})$ containing $40.8 \mathrm{~kg} \mathrm{P} \mathrm{ha}^{-1}$, and 3) Rock phosphate at 1,200 kg ha-1 ( 15\% total P content with very low solubility).

\subsection{Soil sampling and analysis}

182 Soil samples were collected in May 2005 from four $1 \mathrm{~m} \times 1 \mathrm{~m}$ quadrats located $5 \mathrm{~m}$ inside the treatment plot boundary (Fig. 1A). For consistency, soil samples were taken from each of two furrows and two ridges, formed by ripping. Soil was sampled at 0-5, 5-10, 10-20 and 20$30 \mathrm{~cm}$ depth-intervals to investigate treatments effects on fertiliser distribution down the soil profile. Soil samples were stored in plastic zip lock bags, sealed for transport and re-opened

187 within 24 hours. Samples were air-dried (in a drying room maintained at a constant temperature of $40^{\circ} \mathrm{C}$ ) and sieved to $2 \mathrm{~mm}$ prior to further analysis. For comparative purposes, soils were also sampled from three reference jarrah forest sites and in restored sites prior to the addition of fertiliser. Samples were analysed at a commercial laboratory (CSBP Soil and

191 Plant Laboratories, Bibra Lake, Perth, Australia). Soils were hand textured and phosphate

192 retention index was assessed using the method of Allen and Jeffey (1990). Soil pH was 
determined using a 1:5 ratio of soil: either distilled water or $0.01 \mathrm{M}$ calcium chloride solution and Colwell (available) phosphorus (Colwell, 1963), $\mathrm{NO}_{3}-\mathrm{N}$ and $\mathrm{NH}_{4}-\mathrm{N}$ were also analysed.

\subsection{Floristic survey and analysis}

197 In May 2005, a $20 \mathrm{~m} \times 20 \mathrm{~m}$ plot was established within the centre of each $25 \mathrm{~m} \times 25 \mathrm{~m}$ plot.

198 Each $20 \mathrm{~m} \times 20 \mathrm{~m}$ plot was further divided into twenty $2 \mathrm{~m} \times 2 \mathrm{~m}$ quadrats, with a total of 80

$199 \mathrm{~m}^{2}$ sampled per plot. For each species, species identity, density and percentage cover were

200 recorded separately for each $2 \mathrm{~m} \times 2 \mathrm{~m}$ quadrat. Density and cover were then summed for the 201 entire plot.

\subsection{Statistical Analysis}

204 One-way ANOVA implemented in Minitab 17 (Minitab Inc., State College, PA, US), followed

by Tukey's post hoc test was used to test for an effect of fertiliser treatment on soil $\mathrm{P}$

concentration and vegetation responses (species richness, total density, total cover and nonnative weed species richness). In addition, for four relatively abundant taxa (Acacia celastrifolia, Banksia grandis, Bossiaea ornata and Lomandra spp.) one-way ANOVA was used to test for fertiliser effects on density and cover. Data was tested for normality and did not require transforming. For soil P, the ANOVA was followed by Fisher's Least Significance

211 Difference test.

Multivariate data analysis was undertaken using PRIMER ${ }^{\mathrm{TM}}$ (Plymouth Routines in

213 Multivariate Ecological Research, U.K). Floristic trends were analysed using a nonmetric

214 multi-dimensional scaling - nMDS procedure (using Primer-E Ver 6.0 software, www.primer-

215 e.com) to explore patterns of variation in community composition related to fertiliser

216 treatment. nMDS was selected over other multivariate data analysis methods as it can better

217 explain the spatial configuration of the data with minimal distortion to the structure. The raw 
Tibbett et al.

218 floristic data were initially subjected to a fourth-square root transformation followed by

219 calculation of the Bray-Curtis similarity of the distance between points. Subsequently,

220 ANOSIM was used to test the significance of effects of fertiliser treatment on community

221 composition.

3. RESULTS

\subsection{Effects of fertiliser treatment on soil $N$ and $P$}

With the exception of rock phosphate, P fertilised soils had elevated Colwell-P concentrations compared to the native forest soils, pre-treatment values (Table 1) and the unfertilised control (Fig 1). Across the top-dressed fertilised treatments, Colwell-P was consistently higher in furrows (Fig 1A) than in the ridges formed following ripping (Fig 1B). Furthermore, in the top-dressed treatments elevated Colwell-P was largely restricted to the 0$5 \mathrm{~cm}$ depth. In the incorporated SSP treatment, Colwell-P concentrations were similar in the furrows and ridges at $0-5 \mathrm{~cm}$ depth and there was a more uniform distribution of $\mathrm{P}$ down the soil profile compared with top-dressing (Fig. 1). in furrows (One-way ANOVA, $P>0.05$; Table 3). This pattern was similar for ridges (data not shown). Soil $\mathrm{NH}_{4}{ }^{+}$differed with treatment (One-way ANOVA, $\left.P<0.05\right)$ and was significantly higher in the undisturbed reference forest soils than in restored soils, except for the two SSP treatments where fertiliser was applied in summer (Table 3).

\subsection{Fertiliser effects on plant species richness, density and cover}

241 The SSP and rock phosphate treatments had significantly reduced native plant species

242 richness compared with the control and NPK treatment (One-way ANOVA, $P<0.05$; Fig. 
243 2A). On average, across the SSP and rock phosphate treatments there were 10.7 fewer native

244 species per plot compared with the control (58.2 species per plot). Stem density in the control

245 and NPK treatments was similar, and both were significantly higher than in the rock

246 phosphate treatment (Fig. 2B).

The number of non-native weed species was highest in the two fertiliser incorporation treatments (rock phosphate and SSP) and all fertiliser treatments had significantly higher weed species richness than the control (One-way ANOVA, $P<0.05$; Fig. 2C). Total plant cover also responded significantly to fertiliser treatment (One-way ANOVA, $P<0.05$; Fig. 2D) and was highest in the two fertiliser incorporation treatments (rock phosphate and SSP) and lowest in the control. Fertiliser addition resulted in cover being up to six times higher 253 (SSP incorporated down the profile) than the control.

\subsection{Fertiliser effects on taxa level responses}

For all four taxa for which responses were individually investigated, fertiliser treatment had significant effects on both stem density and total percentage cover (One-way ANOVA, $P<$ 0.05; Fig. 3). For A. celastrifolia, both stem density and total cover were highest in the two fertiliser incorporation treatments and lowest in the control. For example, cover in the two incorporation treatments ranged from 26-30\% compared with ca. $3 \%$ cover in the control treatment (Fig. 3B).

Stem density of Banksia grandis was significantly lower in the rock phosphate treatment compared with the other five treatments (One-way ANOVA, $P<0.05$; Fig. 3C). Total cover of $B$. grandis was significantly lower in the rock phosphate, SSP incorporation and top-dressed SSP in summer treatments compared with the control treatment. 
3E). Percentage cover of $B$. ornata was also significantly affected by treatment with cover being highest in the control followed by the NPK treatment. For example, cover of B. ornata in the control was more than four times higher than in the SSP incorporation treatment. All of the fertiliser treatments resulted in a significant reduction in the stem density

272 of Lomandra species compared with the control (One-way ANOVA, $P<0.05$; Fig. 3G).

273 Cover of the Lomandra species was also significantly reduced in all the fertiliser addition treatments: cover was approximately three times higher in the control than the fertiliser treatments.

\subsection{Community level responses to fertiliser treatments}

In the MDS ordination, there was significant overlap in vegetation composition among the

279 five fertiliser treatments. The control plots appeared to cluster as a separate group. (Fig. 4).

280 This was supported by the ANOSIM which indicated a significant effect of fertiliser

281 treatment on community composition (global $\mathrm{r}=0.141, P<0.05$; Table 4). Pair-wise

282 comparisons among the six treatments indicated that all five of the fertiliser treatments had a

283 significant impact on community composition relative to the control $(P<0.05)$. Based on the 284 magnitude of the r-statistic the community composition in the NPK treatment was most 285 similar to the control (Table 4). 


\section{Discussion}

288 Fertiliser application is generally a routine step in mine restoration, with fertiliser typically

289 top-dressed either concurrent with, or following, seeding (e.g. Spain et al., 2015; Koch,

290 2007). However, our current data indicate that when fertiliser was applied as a top-dressing,

291 available-P remains concentrated within the top $5 \mathrm{~cm}$ of soil, predominately within the

292 furrows caused by ripping. In contrast, when the fertiliser was incorporated, the distribution

293 of P down the soil profile was more even and, in agreement with our first hypothesis, resulted

294 in increased plant growth. Phosphorus is generally relatively immobile in soil and is rapidly

295 sorbed as iron and aluminium hydroxides in jarrah forest soils (Lambers et al., 2008);

296 available-P can remain elevated, close to the soil surface, for 20 or more years in both the

297 jarrah forest and elsewhere following a single top-dressed application (Banning et al., 2008;

298 Spain et al., 2018; Daws et al., 2019b). Consequently, there may be long-term impacts on the

299 distribution of $\mathrm{P}$ down the soil profile depending on the method of fertiliser application.

$300 \quad$ In restored mine sites where rapid drying of surface soils may occur, especially during

301 summer in Mediterranean climates such as in the jarrah forest, the availability of

302 shallow/surface applied fertilisers may be further restricted compared with fertiliser incorporated throughout the soil profile. This will particularly be the case for $\mathrm{P}$ as diffusion of

304 phosphate ions to plants is limited in dry soil (Nye and Tinker, 1977). Indeed, surface application can limit uptake of applied $\mathrm{P}$ and crop yields in a range of agricultural systems

306 (Piper and de Vries, 1964; Scott, 1973; Jarvis and Bolland, 1991; Nable and Webb, 1993;

307 Sander and Eghbell, 1999; Teutsch et al., 2000; Singh et al., 2005). In a mine restoration context these results suggest that the same growth benefit resulting from a top-dressed application may be achievable at lower application rates if the fertiliser is incorporated. cover may be advantageous through an increase in site stabilisation and reduction in erosion 
312 risk. Vegetation cover has a significant effect on controlling run-off and soil erosion when at

313 least $30-40 \%$ of the soil surface is covered (Thornes, 1988; Thornes, 1990). While cover was

314 less than $10 \%$ in the control, both of the fertiliser incorporation treatments resulted in total

315 cover in excess of $30 \%$ within the first twelve months after seeding, demonstrating the

316 potential of fertiliser addition, and especially fertiliser incorporation, for reducing erosion.

317 The P-supply in soils is typically heterogeneous and consequently most plant roots

318 grow preferentially in regions that contain high concentrations (Drew, 1975; Fransen et al.,

319 1999; Hodge, 2004). For example, in agricultural systems, when fertiliser is applied as a band

320 beneath or adjacent to seeds, root proliferation is encouraged in the region of the band

321 (Anghinoni and Barber, 1980; Yao and Barber, 1986, Sander et al., 1990). Consequently, a

322 top-dressed application may encourage root proliferation in surface soils with a potential

323 negative impact on seedling survival during summer drought. While we did not investigate

324 root distribution down the soil profile in our current study, $\mathrm{P}$ placement at the surface altered

325 root distributions in two Australian native herbs (Denton et al., 2006). Incorporating fertiliser

326 down the soil profile would militate against this risk. Further studies of the impacts of

327 fertiliser incorporation on root responses in restored systems, and potential impacts on seedling survival during summer drought would be of value.

In support of hypothesis 2, fertiliser application increased overall plant growth, and

330 generally resulted in fewer native species and more weed species than the control. Fertiliser

331 addition has been demonstrated to increase weed growth in a range of restoration studies

332 (Whisenant, 1999; Prober and Wiehl, 2012) and weed proliferation may impact negatively on

333 establishing native species (Nussbaumer et al., 2016). Further, other recent studies in restored

334 Jarrah forests have shown that unfertilised treatments are more similar in composition to

335 native Jarrah forest communities than fertilised treatments (Daws et al., 2013, 2015, 2019a).

336 On an individual species / taxa level, there were also mixed responses to fertiliser application. 
337 The understorey legume Acacia celastrifolia responded vigorously to all fertiliser treatments,

338 but especially incorporation. $\mathrm{N}_{2}$-fixing legumes, such as A. celastrifolia, are generally P-

339 rather than $\mathrm{N}$-limited and many respond vigorously to applied-P in mine restoration (Grant et

340 al., 2007; Daws et al., 2015, 2019b). Indeed, higher soil $\mathrm{NH}_{4}{ }^{+}$concentrations in the single

341 superphosphate incorporation treatment compared with the control (12 versus $2.2 \mathrm{mg} \mathrm{kg}^{-1}$,

342 respectively) likely reflect greater growth and $\mathrm{N}_{2}$-fixation by legume species such as $A$.

343 celastrifolia (Hingston et al., 1982; Koutika et al. 2014). In contrast, B. ornata and Lomandra

344 spp. responded negatively to all the fertiliser treatments. B. ornata is a small, slow growing

345 shrub and Lomandra spp. are small, grass-like understorey plants. While the negative effect

346 of applied fertiliser on abundance / growth of these taxa may be mediated by direct negative

347 effects of P (e.g. Lambers et al., 2002; Williams et al., 2019), it is also likely that these slow-

348 growing species are susceptible to competition from highly $\mathrm{P}$ responsive species such as $A$.

349 celastrifolia. Indeed, negative competitive effects of vigorous legume growth, in response to

350 applied P, on slow-growing understorey species have been reported elsewhere (e.g. Boyes et

351 al., 2011; Le Stradic et al., 2014; Daws et al., 2015, 2019ab), and may be a key mechanism

352 altering species competitive dynamics and consequent ecological trajectories.

353 Banksia grandis (proteaceae) is a mid-storey tree that produces cluster roots to

354 facilitate P uptake in P-deficient soils (Lambers et al., 2002). Many proteaceae including $B$.

355 grandis are sensitive to high levels of applied-P (Shane et al. 2004; Handreck 1991; Lambers

356 et al., 2002; de Campos et al., 2013) as they have limited ability to regulate P uptake when

357 external concentrations are high (Shane et al., 2004). Whilst relatively unresponsive to top-

358 dressed fertiliser application, abundance and cover were reduced when $\mathrm{P}$ (including rock

359 phosphate) was incorporated further reinforcing the suggestion that P-availability to plants

360 may be greater when fertiliser is incorporated. It seems likely that the potentially toxic effects 
of $\mathrm{P}$ on these $\mathrm{P}$-sensitive species are minimised when $\mathrm{P}$ is applied as a top-dressing, presumably due to roots being placed away from surface soils where $\mathrm{P}$ is concentrated. Fertiliser type had a significant and contrasting effect on available $\mathrm{P}$ and $\mathrm{N}$ and on plant communities. The rock phosphate treatment had the seemingly incongruous effect of affecting plant responses while having no effect on available (Colwell)-soil P. In terms of use as a fertiliser in agriculture, rock phosphates have been concluded to be ineffective because they do not dissolve rapidly in Western Australian soil (Boland and Gilkes, 1990). However, the gradual release of phosphate ions from the mineral may be appropriate for the restoration of native forest as applied rock phosphate is known to leave a considerable residue of undissolved rock phosphate in the soil for several years after application. The lack of detectable differences in soil test $\mathrm{P}$ is likely due to the sparing solubility of rock phosphate in the bicarbonate (buffered at $\mathrm{pH}$ 8.5) used as an extractant in Colwell P: studies have concluded that bicarbonate solution poorly predicts potential $\mathrm{P}$ release from the residual rock phosphate in soil (Rajan et al., 1996; Saggar et al., 1999). Despite rock phosphate having low solubility, the impact on plant responses may also have resulted from the rapid release of $\mathrm{P}$ from easily dissolvable mineral surfaces. Indeed, a two-phase release of P from rock phosphate has been reported previously with an initial rapid release of $\mathrm{P}$ from the surface followed by a much lower release of $\mathrm{P}$ as the bulk mineral dissolves (Rafael et al., 2018). In addition, many jarrah forest species, including B. grandis, produce large quantities of carboxylates to release P from strongly sorbed forms (Lambers et al., 2002). Consequently, an alternative explanation for the plant responses to rock phosphate, including the negative effect on growth and abundance of $B$. grandis is carboxylate mediated P dissolution. Despite having the same $\mathrm{P}$ application rate as the P-only treatments, the species richness in the NPK treatment was significantly higher than all but one P-only treatment and was similar to the unfertilised control (Figure 2A). Further, the NPK treatment had a smaller 
negative effect on abundance and / or cover of B. ornata and Lomandra species. Consistent

with the univariate results, our multivariate ANOSIM indicated that the community composition in the NPK treatment was the least different to the unfertilised plots, providing little support for our third hypothesis, and suggesting some interaction with $\mathrm{N}$ fertilisation that our simple soil analysis may not be detecting. ANOSIM also revealed a significant effect of all fertilisers on plant community composition, where all five of the fertiliser treatments caused a significant shift in relative floristic composition compared to unfertilised plots. This demonstrates clearly that fertilisers have an unbalanced effect on early forest development, that is quite different to simply encouraging greater uniform plant growth. In fact, the effects we show are highly selective on a species by species basis. While being far from conclusive, we can postulate that lower rate fertiliser regimes may be more suitable for this forest, and that the effect of co-applied $\mathrm{N}$ needs to be better understood in terms of plant community response. fertilisers may, at least initially, maintain a more natural N:P ratio in the soil. It is also possible that applying $\mathrm{N}$ limits the establishment / reduces the competitiveness of $\mathrm{N}_{2}$ fixing species. Indeed, nitrate and ammonium addition can depress nodule prediction in seedlings of Acacia species (e.g. A. auriculiformis; Goi et al., 1992). Notably, despite containing the same quantity of $\mathrm{P}$ as the single superphosphate treatments, the NPK fertiliser treatment resulted in soil ammonium concentrations $\left(3.1 \mathrm{mg} \mathrm{kg}^{-1}\right)$ that were nearly as low as in the control, $(3.12 .2$ $\mathrm{mg} \mathrm{kg}^{-1}$; Table 3), suggesting a lower rate of atmospheric $\mathrm{N}_{2}$-fixation by legumes (Koutika et al., 2014).

Soil ammonium concentrations were also considerably higher in the native (unmined) forest soils compared to all experimental plots, including those fertilised with nitrogen. After 410 P fertilisation in particular, our data suggest that this may signify a shift in ecosystem 
411 stoichiometry, changed from a natural state of P limitation to an $\mathrm{N}$-limited system, at least in

412 the initial stages after restoration. Studies on the biogeochemistry of these restored forest

413 systems is required to confirm this supposition.

414 Finally, our data indicated that there were no effects of the timing of fertiliser

415 application on species richness, individual species or plant community composition providing

416 no support for our fourth hypothesis that having fertiliser present from the start of restoration

417 will be beneficial. Consequently, this current study provides no support to change from a

418 winter to summer top-dressing. However, since these developing plant communities were

419 only 12 months old when sampled, longer-term studies of the effect of fertiliser treatment on

420 community development would be of value.

421

422 5. Conclusion

423 Ultimately, restoration practitioners aim to achieve a rate of fertiliser application that both

424 compensates for nutrient losses and reflects the aims of restoration. Our current study

425 suggests that if the aims of restoration are to maximise ground cover (to minimise erosion or

426 maximise productivity), then higher rates of fertiliser application and fertiliser incorporation

427 might be needed, while to maximise floristic diversity little or no fertilisation may be

428 appropriate. To optimise the use of fertiliser in mine site restoration to address these

429 competing outcomes will require a better understanding of the effects of applied fertiliser,

430 including longer term impacts.

431

432 


\section{Acknowledgements}

434 Our thanks to M. Smirk, E. Walker, and R. Beazley for laboratory assistance and collecting 435 field samples. We are particularly grateful to M. Brainbridge for his management of the 436 inception of the trial and his subsequent soil sampling and laboratory work, and to Libby

437 Matiske for expert floristic survey of the forest plots. This work was previously presented at 438 the Mine Closure Seminar in Perth September 2006.

439

440 


\section{$441 \quad$ References}

442 Allen, D.G., Jeffrey, R.C. 1990. Methods for analysis of phosphorus. Western Australian Soil $443 \quad$ Report of Investigation No.37 Chemistry Centre WA, p. 37

444 Anghinoni, I., Barber, S.A., 1980. Phosphorus application rate and distribution in the soil and 445 phosphorus uptake by corn. Agron. J. 44, 1041-1044.

446 Australian Bureau of Meteorology (2021) Climate Data Online. Australian Government 447 Bureau of Meteorology, Melbourne, Vic., Australia. Available at http://www. $448 \quad$ bom.gov.au/climate/data/. Accessed 20 April 2021.

449 Banning, N.C., Grant, C.D., Jones, D.L., Murphy, D.V., 2008. Recovery of soil organic 450 matter, organic matter turnover and nitrogen cycling in a post-mining forest rehabilitation 451 chronosequence. Soil Biol. Biochem. 40, 2021-2031.

452 Boland, M.D.A., Gilkes, R.J., 1990. Rock phosphates are not effective fertilizers in Western 453 Australian soils: a review of one hundred years of research. Fert. Res. 22, 79-95.

454 Boyes, L.J., Gunton, R.M., Griffiths, M.E., Lawes, M.J., 2011. Causes of arrested succession 455 in coastal dune forest. Plant Ecol. 212, 21-32.

456 Colwell, J.D., 1963. The estimation of the phosphorus fertilizer requirements of wheat in 457 southern New South Wales by soil analysis. Aust. J. Exp. Agr. 3, 190-7.

458 Daws, M.I., Standish, R.J., Koch, J.M., Morald, T.K. 2013. Nitrogen and phosphorus 459 fertiliser regime affect jarrah forest restoration after bauxite mining in Western Australia. $460 \quad$ Appl. Veg. Sci. 16, 610-618.

461 Daws, M.I., Richardson, C., 2015. An operational scale assessment of the effects of a 462 reduction in fertiliser application rates on plant species responses in jarrah forest restored 463 after bauxite mining Alcoa of Australia Ltd., Research Note No. 38. 
Tibbett et al.

464 Daws, M.I., Standish, R.J., Koch, J.M., Morald, T.K., Tibbett, M., Hobbs, R.J., 2015.

465 Phosphorus fertilisation and large legume species affect jarrah forest restoration after 466 bauxite mining. Forest Ecol. Manage. 354, 10-17.

467 Daws, M.I., Grigg, A.H., Tibbett, M., Standish, R.J., 2019a. Enduring effects of large 468 legumes and phosphorus fertiliser on jarrah forest restoration 15 years after bauxite 469 mining. Forest Ecol. Manage. 438, 204-214.

470 Daws, M.I., Grigg, A.H., Standish, R.J., Tibbett, M., 2019b. Applied phosphorus has long471 term impacts on vegetation responses in restored jarrah forest, In: A.B. Fourie and M. Tibbett (eds.) Proceedings of the $13^{\text {th }}$ International Conference on Mine Closure, 473 Australian Centre for Geomechanics, Perth, pp. 693-704.

474 de Campos, M.C.R., Pearse, S.J., Oliveira, R.S., Lambers, H., 2013. Downregulation of net 475 phosphorus-uptake capacity is inversely related to leaf phosphorus-resorption proficiency 476 in four species from a phosphorus-impoverished environment. Ann. Bot. 111, 445-454.

477 Denton, M.D., Sasse, C., Tibbett, M., Ryan, M.H., 2006. Root distributions of Australian 478 herbaceous perennial legumes in response to phosphorus placement. Funct. Plant Biol. 33, $479 \quad 1091-1102$.

480 Drew, M.C., 1975. Comparison of the effects of a localized supply of phosphate, nitrate, 481 ammonium and potassium on the growth of the seminal root system, and the shoot, in $482 \quad$ Barley. New Phyt. 75, 479-490.

483 Eckert, D.J., 1985. Review: effects of reduced tillage on the distribution of soil $\mathrm{pH}$ and 484 nutrients in soil profiles. J. Fert. Issues 2, 86-90.

485 Food and Agriculture Organization of the United Nations 2012, Harmonized World Soil

486 Database v 1.2, http://www.fao.org/soilsportal/soil-survey/soil-maps-and-

487 databases/harmonized-world-soil-database-v12/en/ 
Fransen, B., Blijjenberg, J., de Kroon, H., 1999. Root morphological and physiological plasticity of perennial grass species and the exploitation of spatial and temporal heterogeneous nutrient patches. Plant Soil 211, 179-189.

Gardner, J.H., Bell, D.T., 2007. Bauxite mining restoration by Alcoa World Alumina Australia in Western Australia: social, political, historical, and environmental contexts. Restor. Ecol. 15, S3-S10.

George, S.J., Tibbett, M., Braimbridge, M.F., Davis, S.G., Vlahos, S. Ryan, M., 2006. Phosphorus fertiliser placement and seedling success in Australian jarrah forest, In: A.B. Fourie and M. Tibbett (eds.) Proceedings of the 1st International Conference on Mine Closure, Australian Centre for Geomechanics, Perth, pp. 341-349.

Goi, S.R., Sprent, J.I., James, E.K., Jacob-Neto, J., 1992. Influence of nitrogen form and concentration on the nitrogen fixation of Acacia auriculiformis. Symbiosis 14, 115-122.

Grant, C.D., Ward, S.C., Morley, S.C., 2007. Return of ecosystem function to restored bauxite mines in Western Australia. Restor. Ecol. 15, S94-S103.

Handreck KA., 1991. Interactions between iron and phosphorus in the nutrition of Banksia ericifolia L. f. var. ericifolia (Proteaceae) in soil-less potting media. Aust. J. Bot. 39, $373-384$.

Hingston, F.J., O'Connell, A.M., Grove, T.S. 1989. 'Nutrient cycling in the jarrah forest', in B Dell, Havel, J.J. and Malajczuk, N. (eds.), The Jarrah Forest: A Complex Mediterranean Ecosystem, Kluwer Academic Press, Dordrecht, pp. 155-177.

Hingston, F.J., Malajcsuk, N., Grove, T.S., 1982. Acetylene reduction (N2-fixation) by jarrah forest legumes following fire and phosphate addition. J. Appl. Ecol. 19, 631-645.

Hodge, A., 2004. The plastic plant: root responses to heterogeneous supplies of nutrients. New Phyt. 162, 9-24. 
Tibbett et al.

512 Holmes, P.M., 2001. Shrubland restoration following woody alien invasion and mining:

513 effects of topsoil depth, seed source, and fertilizer addition. Restor. Ecol. 9, 71-84.

514 Humphrys, H., 1987. An assessment of fertiliser requirements of seeded understorey species

515 of a jarrah forest on a rehabilitated, bauxite mined pit. Applied Mini Project. Curtin

516 University of Technology. In "Proceedings of the MEDECOS XI 2007 Conference, 2-5

517 September, Perth, Information. Food and Agricultural Organization of the United Nations,

$518 \quad$ Rome, pp. 108,

519 Jarvis, R.J., Bolland, M.D.A., 1991. Lupin grain yields and fertiliser effectiveness are

520 increased by banding superphosphate below the seed. Aust. J. Exp. Agr. 31, 357-366.

521 Koch, J.M., 2007. Alcoa's mining and restoration process in South Western Australia. Restor.

$522 \quad$ Ecol. 15, S11-S16.

523 Koutika L-S., Epron, D., Bouillet, J-P. \& Marescha, L. 2014. Changes in N and C

524 concentrations, soil acidity and $\mathrm{P}$ availability in tropical mixed acacia and eucalypt

525 plantations on a nutrient-poor sandy soil. Plant Soil 379, 205-216.

526 Lambers, H., Juniper, D., Cawthray, G.R., Veneklaas, E.J., Martinez-Ferri, E., 2002. The

527 pattern of carboxylate exudation in Banksia grandis (Proteaceae) is affected by the form of 528 phosphate added to the soil. Plant Soil 238, 111-122.

529 Lambers, H., Raven, J.A., Shaver, G.R., Smith, S.E., 2008. Plant nutrient-acquisition strategies $530 \quad$ change with soil age. Trends Ecol. Evo. 23, 95-103.

531 Le Stradic, S., Buisson, E., Negreiros, D., Campagne, P., Fernandes, G.W., 2014. The role of 532 native woody species in the restoration of Campos Rupestres in quarries. Appl. Veg. Sci. $533 \quad 17,109-120$. 
Tibbett et al.

534 Lockley, I.R., Koch, J.M., 1996. Response of two eucalypt species to fertilizer application on rehabilitated bauxite mines in Western Australia. Environment Department Research Bulletin No. 19, Alcoa of Australia Ltd., Pinjarra, Western Australia.

Mackay, A.D., Kladivko, E.J., Barber, S.A., Griffith, D.R., 1987. Phosphorous and potassium uptake by corn in conservation tillage systems. Soil Sci. Soc. Am. J. 51, 970-974.

Malakondaiah, N., Safaya, N.M., Wali, M.K., 1981. Responses of alfalfa and barley to spoil and foliar applications of $\mathrm{N}$ and $\mathrm{P}$ on a coal mine spoil. Plant Soil 59, 441-453.

McArthur, W. M. (1991). Reference soils of south-western Australia. Dept. of Agriculture, Western Australia on behalf of the Australian Society of Soil Science.

Morrison, J.E. Jr., Chichester, F.W., 1994. Tillage system effects on soul and plant nutrient distribution on Vertisols. J. Prod. Agric. 7, 364-373.

Nable, R.O., Webb, M.J., 1993. Further evidence that zinc is required throughout the root zone for optimal plant growth and development. Plant Soil 150, 247-253.

Nemchin, A.A., Pidgeon, R.T., 1997. Evolution of the Darling range batholith, Yilgarn craton, western Australia: a SHRIMP zircon study. Journal of Petrology, 38(5), 625-649.

549 Nussbaumer, Y., Cole, M.A., Offler, C.E., Patrick, J.W., 2016. Identifying and ameliorating nutrient limitations to reconstructing a forest ecosystem on mined land. Restor. Ecol. 24, $202-211$.

Nye, P.H., Tinker, P.B., 1977. Solute Movement in the Soil-root System. Blackwell Science Publishers, Oxford.

554 Piper, C.S., de Vries, M.P., 1964. The residual value of superphosphate on a red-brown earth in South Australia. Aust. J. Agr. Res. 15, 234-272.

Prober, S.M., Wiehl, G., 2012. Relationships among soil fertility, native plant diversity and exotic plant abundance inform restoration of forb-rich eucalypt woodlands. Divers. 
Rafael, R.B.A., Fernandez-Marcos, M.L., Cocco, S., Ruello, M.L., Weindorf, D.C., Cardelli, V., Corti, G., 2018. Assessment of potential nutrient release from phosphate rock and dolostone for application in acid soils. Pedosphere 28, 44-58.

Rajan, S.S.S., Watkinson, J.H., Sinclair. A.G., 1996. Phosphate rocks for direct application to soils. Adv. Agron. 57, 77-159.

Rokich, D.P., Dixon, K.W., 2007. Recent advances in restoration ecology, with a focus on the Banksia woodland and the smoke germination tool. Aust. J. Bot. 55, 375-389.

Ryan, M.H., Tibbett, M., Lambers, H., Bicknell, D., Brookes, P., Barrett-Lennard, E., O’Campo, C., Nicol, D., 2017. Pronounced surface stratification of soil phosphorus, potassium and sulfur under pastures upstream of a eutrophic wetland and estuarine system. Soil Res. 55, 657-669

Saggar, S., Hedley, M.J., White, R.E., Perrott, K.W., Gregg, P.E.H., Cornforth, I.S., Sinclair, A.G., 1999. Development and evaluation of an improved soil test for phosphorus, 3: field comparison of Olsen, Colwell and resin soil P tests for New Zealand pasture soils. Nutr. Cycl. Agroecosys. 55, 35-50.

Sander, D.H., Penas, E.J., Eghball, B., 1990. Residual effects of various phosphorus application methods on winter wheat and grain sorghum. Soil Sci. Soc. Am. J. 54, 14731478.

Sander, D.H., Eghball, B., 1999. Planting date and phosphorus fertiliser effects on winter

579 Scott, B.J., 1973., The response of barrel medic pasture to topdressed and placed

580 superphosphate in western New South Wales. Aust. J. Exp. Agr. 13, 705-710.

581 Shane. M.W., Szota, C., Lambers, H., 2004a. A root trait accounting for the extreme phosphorus sensitivity of Hakea prostrata (Proteaceae). J. Exp. Bot. 27, 991-1004. 
583 Singh, D.K., Sale, P.W.G., Routley, R.R., 2005. Increasing phosphorus supply in subsurface

584 soil in northern Australia: Rationale for deep placement and the effects with various crops. $585 \quad$ Plant Soil 269, 35-44.

586 Sloan, J.L., Uscola, M., Jacobs, D.F., 2016. Nitrogen recovery in planted seedlings,

587 competing vegetation, and soil in response to fertilization on a boreal mine reclamation $588 \quad$ site. For. Ecol. Manage. 360, 60-68.

Soliveres, S., Monerris, J., Cortina, J., 2012. Irrigation, organic fertilization and species successional stage modulate the response of woody seedlings to herbaceous competition in a semi-arid quarry restoration. Appl. Veg. Sci. 15, 175-186.

Spain, A.V., Tibbett, M., Hinz, D.A., Ludwig J.A., Tongway, D.J., 2015. The miningrestoration system and ecosystem development following bauxite mining in a biodiverse environment of the seasonally dry tropics, Northern Territory, Australia. In: M. Tibbett (ed.) Mining in Ecologically Sensitive Landscapes, pp. 159-227. CRC Press, Netherlands

Spain, AV., Tibbett, M., Ridd, M., McLaren, T.I., 2018. Phosphorus dynamics in a tropical forest soil restored after strip mining. Plant Soil 427, 105-123.

Standish, R.J., Daws, M.I., Gove A.D., Didham, R.K., Grigg, A.H., Koch, J.M., Hobbs, R.J., 2015. Long-term data suggest jarrah-forest establishment at restored mine sites is resistant to climate variability. J. Ecol. 103, 78-89.

601 Standish, R. J., Tibbett, M., Vlahos, S., Stokes B. A. \& Hobbs, R. J., 2010. The effect of 602 fertiliser on floristic diversity and composition of early-successional jarrah forest restored 603 after bauxite mining in south-western Australia. In: A. B. Fourie, M. Tibbett \& J. Wiertz 604 (eds.) Proceedings of the Fifth International Conference on Mine Closure, Santiago, Chile. 605 Australian Centre for Geomechanics, Perth. pp 387-395. Australian Centre for 606 Geomechanics, Perth. 
Tibbett et al.

607 Teutsch, C.D., Sulc, R.M., Barta, A.L., 2000. Banded phosphorus effects on alfalfa seedling

608 growth and productivity after temporary waterlogging. Agron. J. 92, 48-54.

609 Tibbett, M., 2010. Large-scale Mine Site Restoration of Australian Eucalypt Forests After

610 Bauxite Mining: Soil Management and Ecosystem Development. In: L.C. Batty \& K.

611 Hallberg. (eds.) Ecology of Industrial Pollution, pp. 309-326. Cambridge University Press, $612 \quad$ UK.

613 Thornes, J.B., 1988. Erosional equilibria under grazing. In: Bintliff, J., Davidson, D. \& Grant,

614 E. (eds.) Conceptual issues in environmental archaeology, pp. 193-210. Edinburgh

$615 \quad$ University Press, Edinburgh, UK.

616 Thornes, J.B., 1990. Vegetation and erosion: processes and environment. John Wiley \& 617 Sons, Chichester, UK.

618 USDA., 1999. Soil Taxonomy A Basic System of Soil Classification for Making and

619 Interpreting Soil Survey. United States Department of Agriculture - Natural Resources

620 Conservation Service, Agricultural Handbook Number 436.

621 Wali, M.K., 1999. Ecological succession and the rehabilitation of disturbed terrestrial 622 ecosystems. Plant Soil 213, 195-220.

623 Ward, S.C., Koch, J.M., Nichols, O.G., 1990. Bauxite mine rehabilitation in the Darling Range, 624 Western Australia. Proc. Ecol. Soc. Aust. 16, 557-565.

625 Whisenant, S.G., 1999. Repairing damaged wildlands. Cambridge University Press, 626 Cambridge, UK.

627 Williams, A., George S., Birt, H.W.G, Daws, M.I., Tibbett, M., 2019. Sensitivity of seedling 628 growth to phosphorus supply in six tree species of the Australian Great Western

629 Woodlands. Aust. J. Bot. 67, 390-396. 
630 Williamson, J.C., Rowe, E.C., Hill, P.W., Nason, M.A., Jones, D.L., Healey, J.R., 2011.

631 Alleviation of both water and nutrient limitations is necessary to accelerate ecological

632 restoration of waste rock tips. Restor. Ecol. 19, 194- 204.

633 Yao, J., Barber, S.A., 1986. Effect of one phosphorus rate placed in different soil volumes on $634 \quad$ P uptake and growth of wheat. Commun. Soil Sci. Plant Anal. 17, 819-827. 
635 Table 1: Soil parameters in unmined forest and in restored sites prior to the addition of

636 fertiliser.

637

\begin{tabular}{|c|c|c|c|}
\hline Parameter & Unit & Unmined forest & Pre-treatment \\
\hline Gravel & $\%$ & $51.5 \pm 14.7$ & $70.0 \pm 2.0$ \\
\hline Texture & Class & Loam & Loam \\
\hline $\mathrm{NO}_{3}^{-}$ & $\mathrm{mg} \mathrm{kg}^{-1}$ & $<1$ & $1.1 \pm 0.1$ \\
\hline $\mathrm{NH}_{4}^{+}$ & $\mathrm{mg} \mathrm{kg}^{-1}$ & 4.32 .0 & $7.0 \pm 1.8$ \\
\hline Total P & $\mathrm{mg} \mathrm{kg}^{-1}$ & $131.6 \pm 11.7$ & ND \\
\hline Colwell P & $\mathrm{mg} \mathrm{kg}^{-1}$ & $3.7 \pm 0.9$ & $3.5 \pm 1.2$ \\
\hline P-retention index & ratio & $90.5 \pm 14.3$ & ND \\
\hline pH (water) & $\mathrm{mg} \mathrm{kg}^{-1}$ & $6.0 \pm 0.1$ & $5.9 \pm 0.1$ \\
\hline $\mathrm{pH}\left(\mathrm{CaCl}_{2}\right)$ & $\mathrm{mg} \mathrm{kg}^{-1}$ & $5.1 \pm 0.1$ & $5.3 \pm 0.1$ \\
\hline Organic C & $\%$ & $5.7 \pm 0.7$ & $4.6 \pm 0.5$ \\
\hline
\end{tabular}

638 
639 Table 2: Details of the six fertiliser treatments used in the current study.

\begin{tabular}{lllll}
\hline Treatment & Fertiliser type & Fertiliser & Timing of & P-application \\
number & & placement & fertiliser & rate $\left(\mathrm{kg} \mathrm{ha}^{-1}\right)$ \\
& & & application & \\
\hline $1 *$ & Single super phosphate & Top-dressed & Winter & 40.8 \\
2 & Single super phosphate & Top-dressed & Summer & 40.8 \\
3 & Single super phosphate & Incorporated & Summer & 40.8 \\
4 & NPK & Top-dressed & Winter & 40.9 \\
5 & Rock phosphate & Incorporated & Summer & 180 \\
6 & Control - No fertiliser & N/A & N/A & 0 \\
& application & & & \\
\hline
\end{tabular}

641

642 
643 Table 3: the effect of fertiliser type and application method on $\mathrm{NO}_{3}{ }^{-}$and $\mathrm{NH}_{4}{ }^{+}$measured at 0-

$6445 \mathrm{~cm}$ depth in the furrows caused by ripping in one-year old restored jarrah forest. For

645 comparison, values for unmined forest were also determined. Treatment numbers relate to the

646 numbers used in Table 1. Data are \pm 1 standard error of the mean.

\begin{tabular}{|c|c|c|c|}
\hline Fertiliser type & Application type & $\begin{array}{l}\text { Soil } \mathrm{NO}_{3} \\
\left(\mathrm{mg} \mathrm{kg}^{-1}\right)\end{array}$ & $\begin{array}{l}\text { Soil } \mathrm{NH}_{4} \\
\left(\mathrm{mg} \mathrm{kg}^{-1}\right)\end{array}$ \\
\hline Single super phosphate & Top-dressed in Winter & $1.8 \pm 1.3^{\mathrm{a}}$ & $6.3 \pm 2.7^{b}$ \\
\hline Single super phosphate & Top-dressed in Summer & $2.1 \pm 0.5^{\mathrm{a}}$ & $13.6 \pm 5.1^{\mathrm{ab}}$ \\
\hline Single super phosphate & Incorporated in Summer & $1.7 \pm 0.6^{\mathrm{a}}$ & $12.0 \pm 3.4^{\mathrm{ab}}$ \\
\hline NPK fertiliser & Top-dressed in Winter & $3.0 \pm 1.0^{\mathrm{a}}$ & $3.1 \pm 2.3^{\mathrm{b}}$ \\
\hline Rock phosphate & Incorporated in Summer & $\leq 1$ & $5.2 \pm 2.1^{b}$ \\
\hline Control - no fertiliser & - & $\leq 1$ & $2.2 \pm 1.3^{\mathrm{b}}$ \\
\hline Unmined forest & - & $2.0 \pm 0.5^{\mathrm{a}}$ & $26.3 \pm 4.3^{\mathrm{a}}$ \\
\hline
\end{tabular}

$647 \overline{\text { Values with the same letters within each column were not significantly different at } P<0.05}$

648 (One-Way ANOVA with Tukey's pairwise comparisons). 
1 Table 4: Pair-wise comparisons of the R-statistic for effects of the six fertiliser treatments on plant community composition in the ANOSIM.

2 Treatment numbers relate to the numbers used in Table 2.

\begin{tabular}{|c|c|c|c|c|c|c|}
\hline Treatment & $\begin{array}{c}\text { SSP top } \\
\text { dressed in } \\
\text { Winter (1) }\end{array}$ & $\begin{array}{c}\text { SSP top- } \\
\text { dressed in } \\
\text { Summer (2) }\end{array}$ & $\begin{array}{c}\text { SSP } \\
\text { incorporated in } \\
\text { Summer (3) }\end{array}$ & $\begin{array}{l}\text { NPK top- } \\
\text { dressed in } \\
\text { Winter (4) }\end{array}$ & $\begin{array}{l}\text { Rock phosphate } \\
\text { incorporated in } \\
\text { Summer (5) }\end{array}$ & $\begin{array}{l}\text { Control } \\
\text { (6) }\end{array}$ \\
\hline SSP top-dressed in Winter (1) & - & & & & & \\
\hline $\begin{array}{l}\text { SSP top-dressed in Summer } \\
\text { (2) }\end{array}$ & -0.011 & - & & & & \\
\hline $\begin{array}{l}\text { SSP incorporated in Summer } \\
\text { (3) }\end{array}$ & -0.039 & -0.102 & - & & & \\
\hline $\begin{array}{l}\text { NPK top-dressed in Winter } \\
\text { (4) }\end{array}$ & 0.111 & 0.228 & 0.148 & - & & \\
\hline $\begin{array}{l}\text { Rock phosphate incorporated } \\
\text { in Summer (5) }\end{array}$ & -0.235 & -0.228 & -0.099 & 0.259 & - & \\
\hline Control (6) & $0.593^{*}$ & $0.667 *$ & $0.647 *$ & $0.298^{*}$ & $0.722 *$ & - \\
\hline
\end{tabular}

3 Test statistic 0.141, 3.9 percent; $* P<0.05$ 


\section{List of Figures}

2 Figure 1: The effect of fertiliser type (single super phosphate [SSP], NPK and rock

3 phosphate), placement (incorporated (INC) and top-dressed (TD)) and timing of application

4 on soil available (Colwell-)phosphorus in (A) furrows and (B) ridges (formed following

5 deep ripping) $(* * * P<0.01$ for pooled Fisher's Least Significant Difference) in one-year-

6 old jarrah forest restored after mining. Vertical bar charts represent $0-5 \mathrm{~cm}$ soil samples and

7 horizontal bar charts represent depth increments. Errors bar are \pm 1 standard error of the

8 mean.

9 Figure 2: The effect of fertiliser type (single super phosphate [SSP], NPK and rock phosphate $10[\mathrm{RP}]$ ), placement (incorporated (INC) and top-dressed (TD)) and timing of application (S:

11 summer, or $\mathrm{W}$ : winter) on vegetation responses (A: native plant species richness, B: total

12 stem density, C: species richness of non-native weed species, and D: total plant cover) in

13 one-year-old jarrah forest restored after mining. Errors bar are \pm 1 standard error of the

14 mean.

15 Figure 3: The effect of fertiliser type (single super phosphate [SSP], NPK and rock phosphate $16[\mathrm{RP}]$ ), placement (incorporated (INC) and top-dressed (TD)) and timing of application (S:

17 summer, or $\mathrm{W}$ : winter) on stem density $(\mathrm{A}, \mathrm{C}, \mathrm{E}, \mathrm{G})$ and percentage cover $(\mathrm{B}, \mathrm{D}, \mathrm{F}, \mathrm{H})$ for

18 four taxa (Acacia celastrifolia, Bossiaea ornata, Banksia grandis and Lomandra spp.) in

19 one-year-old jarrah forest restored after mining. Errors bar are \pm 1 standard error of the

20 mean.

21 Figure 4: NM-MDS of the effect of fertiliser type (single super phosphate [SSP], NPK and rock phosphate [RP]), placement (incorporated (INC) and top-dressed (TD)) and timing of application (S: summer, or W: winter) on vegetation composition in one-year old restored

24 jarrah forest. 


\section{$1 \quad$ Figure 1}
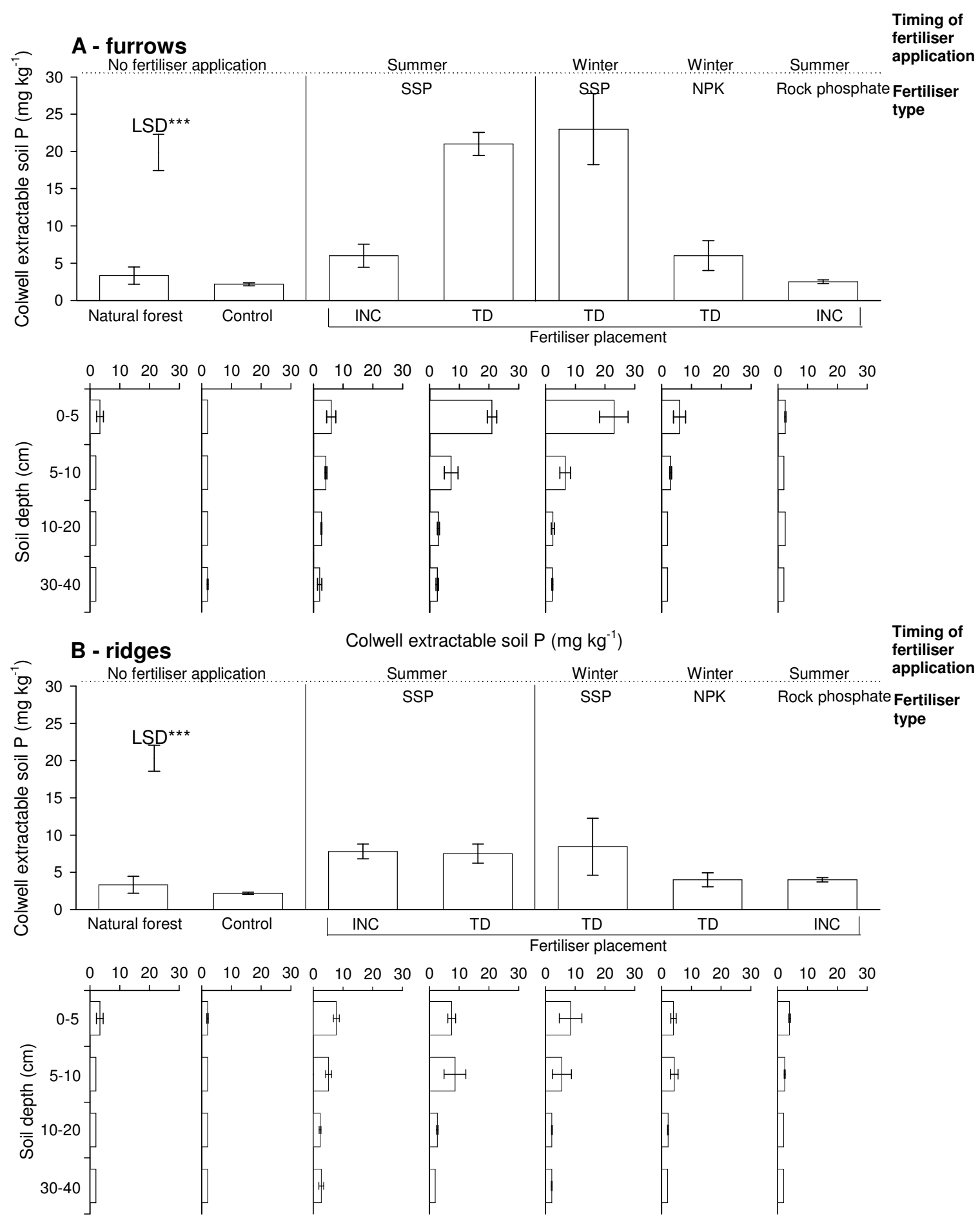

2

Colwell extractable soil $\mathrm{P}\left(\mathrm{mg} \mathrm{kg}^{-1}\right)$

Timing of fertiliser application type 
Tibbett et al.

Page 36

Figure 2

2
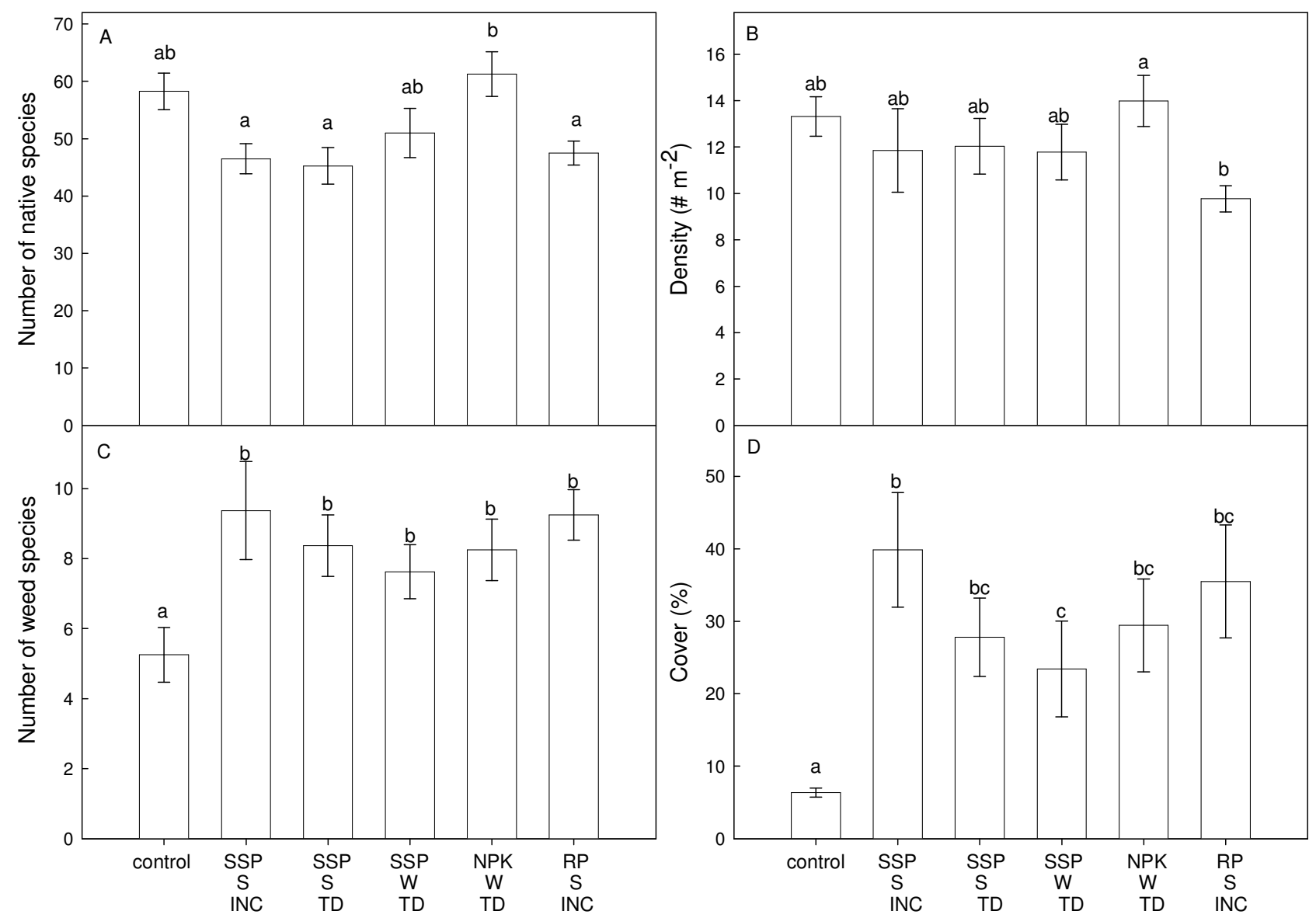

3

4

5

6 
Tibbett et al.

Page 37

$1 \quad$ Figure 3

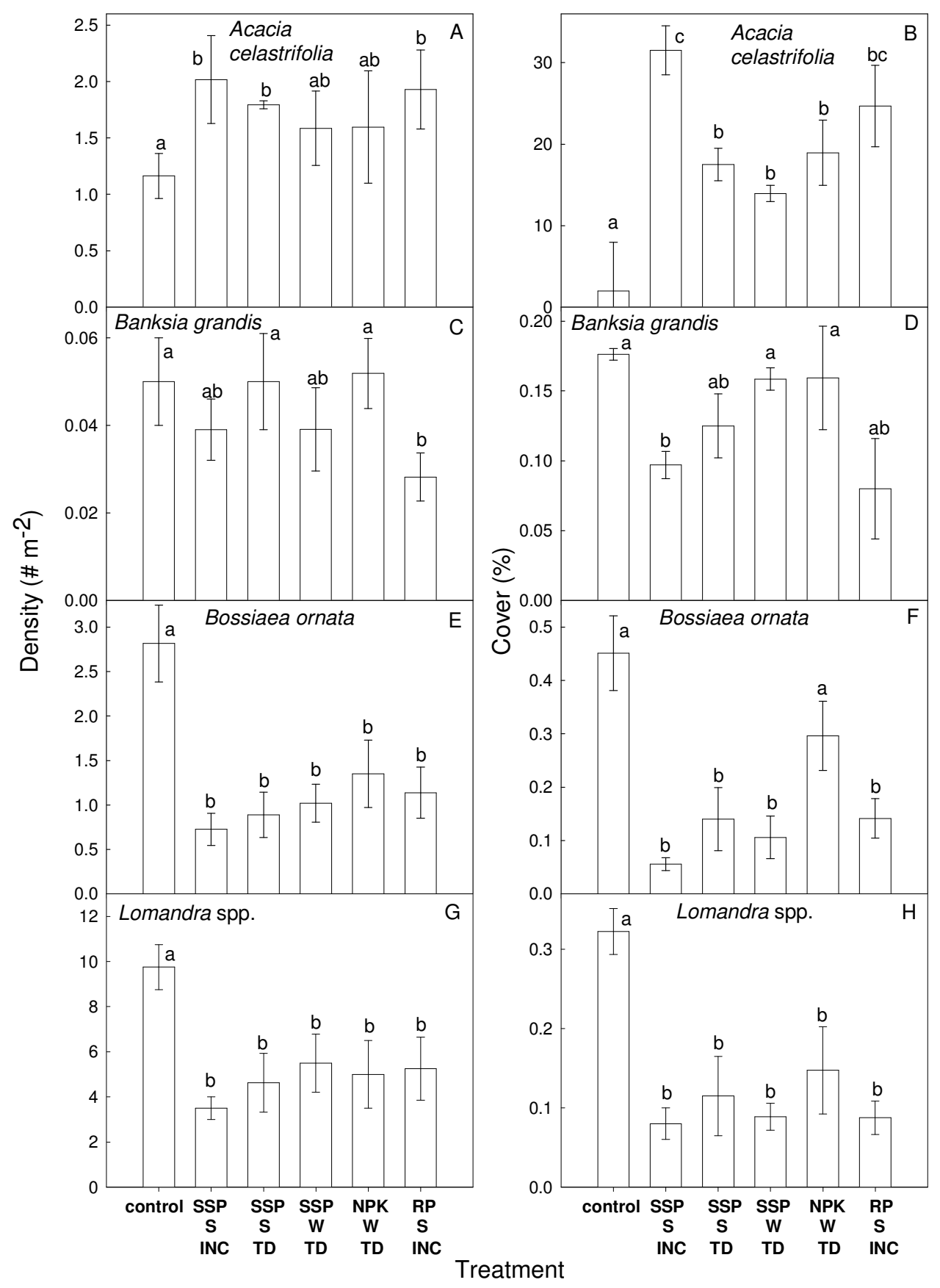




\section{$1 \quad$ Figure 4}

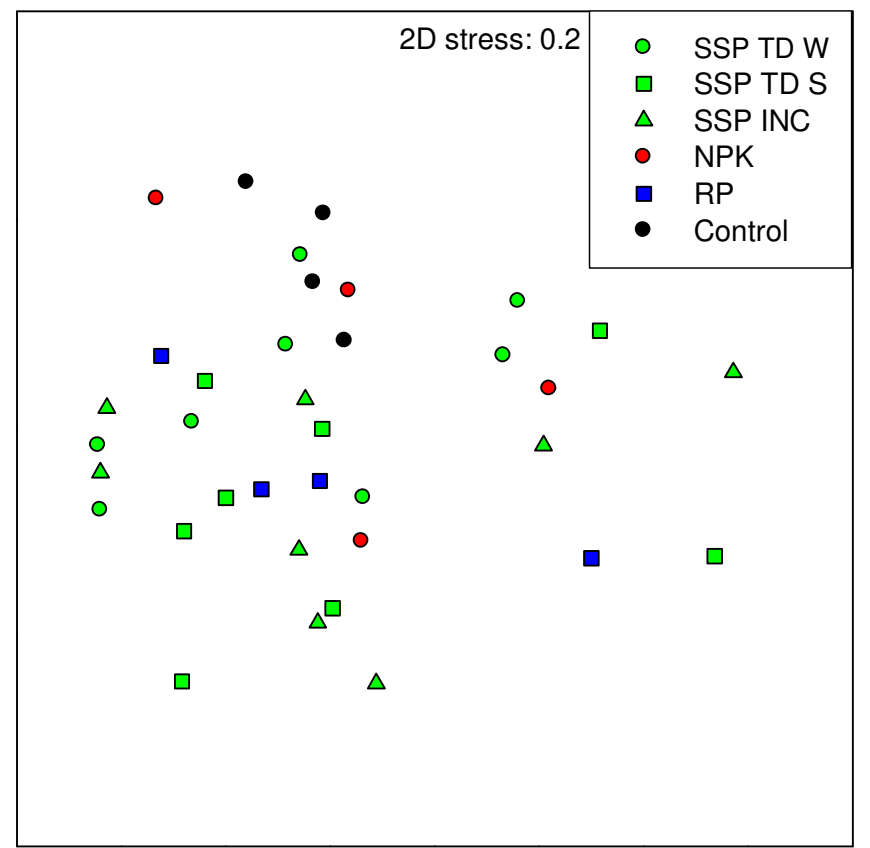

